\title{
O ofício de escritor
}

Entrevista

Alberto Mussa

Alberto Mussa é um escritor brasileiro. Basta contabilizar a sua obra publicada, observar a crítica que a recebeu e os prêmios que a consagrou, no Brasil, e a sua larga recepção internacional, para que a afirmativa assuma todo o seu sentido.

Com a consagração vieram inevitavelmente os lugares comuns sobre a sua obra, então dividida em "três fases". Uma primeira se abre com os romances Elegbara, O trono da rainha Jinga, em que algumas passagens da história do Brasil surgem narradas como mitos; uma segunda, com O enigma de Qaf, O movimento pendular e Meu destino é ser onça, é considerada borgeana; e, numa terceira fase, os livros $O$ senhor do lado esquerdo, $O$ trono da rainha Jinga e A primeira história do mundo ${ }^{1}$ são os três primeiros de um projeto de cinco novelas policiais ambientadas, cada uma, em um dos séculos da história do Rio de Janeiro. Porém, por detrás de "escritor brasileiro" há muito mais do que aquilo que a psicologia expressa numa intenção autoral racionalizada em fases pode supostamente oferecer.

Mussa é um escritor laborioso, que escolheu escrever romances como se escolhe um ofício que exige muita preparação. Proceder à invenção literária, para ele, só é possível a partir de uma arquitetura prévia e geometricamente montada. Disso decorre um domínio que não consiste apenas no uso da técnica com algum grau de excelência, porém num autêntico parti pris da narrativa. É assim que, no lugar da vontade autorreferenciada da ficção contemporânea, nos livros de Alberto Mussa a referência é sempre a grande narrativa histórica - a mesma tantas vezes perdida no horizonte presente dos historiadores —, ou ainda, a dos relatos mitológicos, na sua potência oral, tornados continentes de matéria para a sua escrita ficcional.

Resta ainda a maior e mais nobre parte do ofício, que é a imaginação, assumida por Mussa a partir de um ponto de vista: o de um brasileiro. Foi no gênero policial que a transposição às mitologias locais, particularmente cariocas, encontrou o seu lugar mais propí-

\footnotetext{
${ }^{1}$ São essas as ediçôes dos livros de Alberto Mussa: O enigma de Qaf. Rio de Janeiro: Record, 2004 (2ª edição, 2013); Elegbara. Rio de Janeiro: Revan, 1997 (2 edição, Record, 2005). O movimento pendular. Rio de Janeiro: Record, 2006; O trono da rainha Jinga. Rio de Janeiro: Nova Fronteira, 1999 (2a edição, Record, 2007). Meu destino é ser onça. Rio de Janeiro: Record, 2009; O senhor do lado esquerdo. Rio de Janeiro: Record, 2011 (2ª edição, 2013); A primeira história do mundo. Rio de Janeiro: Record, 2014.
}

DOI - http://dx.doi.org/10.1590/2237-101X0173214 
cio. O Rio de Janeiro antigo é o ambiente por excelência de suas novelas, em que os casos inusitados, tão estranhos quanto maravilhosos, confirmam, sem maiores comemoraçóes, o epíteto da cidade que é a sua. Foi assim, inevitavelmente como brasileiro e carioca, que Alberto Mussa visitou as culturas árabes pré-islâmicas ou a Antiguidade grega, para nos fazer experimentar, em novas formas literárias, o samba, a capoeira, o candomblé ou as línguas portuguesa e tupi. Eles se tornam, desse ponto de vista, elementos, ao mesmo tempo, de uma história anônima e coletivamente partilhada ao longo de séculos e das histórias contadas por um bem-humorado escritor brasileiro.

Foi sobre esse seu ofício que Alberto Mussa falou à revista Topoi. ${ }^{2}$

Andrea DAHER: Inauguramos esta nossa entrevista com uma pergunta sobre seu processo de escrita: como você escreve, no seu cotidiano?

Alberto Mussa: Isso varia muito de acordo com o livro, depende das leituras que eu vou fazer, que eu quero fazer. Até eu montar o meu esqueminha, vou fazendo as minhas leituras, vou pensando na história. Às vezes, eu tenho que fazer mudanças radicais, como aconteceu com meu último livro, $A$ primeira história do mundo, que náo demorei muito a escrever. Mas quando eu resolvo jogar fora o que escrevi, eu jogo fora tudo. Posso aproveitar um trecho que eu ache muito importante. E assim vou polindo o tempo todo. Às vezes eu até sei o texto decorado, de tanto que eu já li e reli. Antes de começar o que eu vou escrever, normalmente já vou lendo o que já escrevi antes, ou pelo menos, a parte que está mais próxima.

Acontece, quando estou dormindo, de lembrar que escrevi uma frase que não ficou bem. Por exemplo, ontem eu escrevi algo, à noite, e não gostei da forma como ficou. Eu terminei porque tinha que dormir e acordar cedo hoje. Vou certamente mexer porque náo gostei das últimas frases, questão de estética mesmo. Não gostei da maneira como escrevi, achei uma imagem vulgar, comum. Às vezes, também, você só percebe que tem que mudar depois, quando o livro vai para a revisão. É muito importante a revisão, porque você descansa um pouco, esquece um pouco do livro, passado um tempo. Depois, quando tem o texto de volta, você vê uma série de coisas a serem mudadas.

Andrea Daher: Gostaria de evitar a explicação psicológica das fases da sua obra e pensar, mais diretamente, a partir do seu procedimento de escrita, nos aspectos que me parecem importantes, presentes em quase todos os seus livros. Um deles, eu diria que é uma busca de origens, num passado histórico (por exemplo, a história do Rio de Janeiro). E, nisso, identifico também um procedimento literário por excelência: refundar. Por exemplo, o crime tem essa função nos seus romances: o crime é um acontecimento que

\footnotetext{
${ }^{2}$ Alberto Mussa foi entrevistado pelos pesquisadores do Laboratório de pesquisa em história das práticas letradas em 29 de outubro de 2015. Esta entrevista foi editada e apresentada por Andrea Daher.
} 
você arbitra, é o inesperado que refunda, refaz a ordem das coisas. Para que a busca de origens e a refundação dos acontecimentos aconteçam nos seus romances, você lança mão do recurso de abrir janelas, que são digressões, plenas de repertórios, em grande parte, de teor etno-histórico ou mítico.

Pergunto, então: como você chegou à construção desses repertórios? De que modo servem à sua narrativa, ou seja, que relação estabelecem com o ambiente histórico e, ao mesmo tempo, com a história que você conta?

Alberto Mussa: Isso vem das minhas leituras. A minha experiência com a leitura é muito antiga, porque a minha casa era cheia de livros, tanto do meu pai quanto do meu avô. Era uma casa com livros em todos os lugares, até na garagem havia livros. O carro ficava na rua porque a garagem era o lugar onde os livros de direito do meu pai ficavam guardados. Meu pai tinha o escritório dele, mas tinha livro no quarto, nos corredores. E uma das poucas coisas que eu não era proibido de fazer era mexer nos livros. O livro era uma coisa permitida.

Depois que os meus irmáos mais novos nasceram, o quarto ficou pequeno, e fui transferido para a parte de baixo da casa (os quartos ficavam em cima), onde havia uma saleta de televisão com umas estantes. Ali ficou sendo o meu quarto. Eu tinha os meus livros também, os livros de que eu gostava, e que dividia com a minha mãe: Agatha Christie, os romances policiais. A minha mãe gostava muito desse gênero, gosta até hoje. Toda semana eu compro dois, três romances policiais para ela não parar de ler (ela já está com quase oitenta anos, e continuo levando livrinhos para ela).

Eu me lembro, por exemplo, de uma coleção, que talvez tenha sido a base desses repertórios, como você os chamou, que era uma coleção sobre civilizações antigas. Uma coleção estrangeira (provavelmente inglesa ou francesa, eu não sei exatamente) traduzida, em que você tinha os povos da Índia, do Egito, de uma parte da África, você tinha a China, o Japão, a América das chamadas civilizações pré-colombianas. Eu me deliciava muito com aquelas histórias, porque ali você tinha um resumo das religiôes, das histórias de deuses.

Por uma via de experiência pessoal, que foi muito importante para mim, vivi um contraste religioso, desde cedo. A família do meu pai era cristã ortodoxa, libanesa — não eram maronitas, não eram católicos, faziam uma questão muito grande de marcar bem essa diferença. Apesar de, na prática, a gente não ver quase diferença nenhuma, para eles era fundamental essa diferença que definia uma etnia: eram árabes ortodoxos, isso era uma marca mais importante do que serem chamados de libaneses, sírios, turcos, ou o que fosse.

Já a família da minha mãe era uma família meio mineira, meio alagoana, uma família curiosa porque tinha uma ala (uma parte das minhas tias) de católicos muito fervorosos. Não vou dizer que eram fanáticos, mas eram católicos que iam à missa. Minha mãe, uma outra tia minha e o Didi (que, aliás, era compositor de samba-enredo) frequentavam tam- 
bém terreiros de umbanda e candomblé. Desde pequeno, frequentei um terreiro de Ogum. Cheguei a ser ogan e toquei atabaque no terreiro de umbanda durante um período. Mais tarde, me tornei também sacerdote, me tornei babalaô (tenho uma série de títulos). Mas essa é uma longa história que a gente pode deixar para depois.

Andrea Daher: De que modo isso teria inaugurado a sua vontade de construir repertórios?

Alberto Mussa: Eu acho que foi isso que me trouxe a primeira curiosidade intelectual. Eu fazia uma brincadeira que era tentar comparar todos os deuses: por exemplo, os deuses astecas com os deuses gregos e com os orixás do candomblé. Estes não estavam na coleção de livros de que eu falava, mas era um conhecimento que eu tinha de uma prática, de uma experiência de vida. Então, eu comecei a tentar fazer essas comparaçôes e senti muita falta de não ter um panteão de deuses brasileiros. Aquilo não existia para mim, naquela época, então comecei a inventar. Inventei um, baseado no jogo do bicho.

Andrea Daher: Mas inventava em imaginação ou escrevia?

Alberto Mussa: Não, eu escrevia. Mas eu não tenho mais essas coisas, não. Eu achava que existia, deveria existir uma correspondência entre as religióes. Talvez eu partisse da ideia de que nenhuma daquelas religióes era verdadeira - eu era ainda muito jovem quando pensava isso - afinal os povos são muito diferentes. Mas, se houvesse alguma verdade naquilo, então eu tentava comparar os deuses. Os deuses da mitologia grega também estavam lá, a Grécia estava contemplada. A mitologia grega é algo com que aprendi, desde muito cedo, a lidar. E me lembro de um livro de Monteiro Lobato também muito importante, nesse sentido, Os doze trabalhos de Hércules. Era o livro dele que eu mais gostava, justamente porque abordava questóes mitológicas.

De certa forma, as coisas que sempre me chamaram a atenção são relativas a modos diferentes de você ver o mundo. Isso foi algo que eu experimentei dentro da minha casa e, de certa forma também, dentro do meu convívio social, porque eu nasci no Grajaú, que na época era um bairro de classe média, tendente para a classe média alta. Um bairro de muitos militares. Nasci pouco antes da ditadura, em 1961, e cresci durante esse período. O Grajaú era um bairro muito conservador, onde havia muitas casas, não havia quase prédios. Ao mesmo tempo, é colado no Andaraí, um bairro mais popular, com um morro, onde eu tinha amigos. Eu sempre tive contato com diferenças, digamos assim, com maneiras diferentes de observar o mundo. E achava isso interessante.

Agora, além dos romances policiais e desses livros sobre religiōes, mitologias, histórias de povos antigos que sempre me interessaram, eu gostava de literatura no geral. Principalmente 
quando criança, entre dez e doze anos, eu lia muita poesia. Eu conhecia bem, por exemplo, os Sonetos de Camóes.

Andrea Daher: E desde essa mesma época você já fazia inventários, construía repertórios?

Alberto Mussa: Sempre fiz muitos inventários, e de muitas coisas, sempre gostei de fazer: por exemplo, fazia o inventário dos títulos das escolas de samba, dos sambas do Salgueiro, dos sambas que falam de índio...

Andrea Daher: Por escrito?

Alberto Mussa: É. Eu tinha uns cadernos, anotava tudo: quem foram os campóes, os primeiros campóes etc. E isso era uma maneira de decorar também, pois você acaba decorando. Eu sempre gostei de fazer essas coisas.

Andrea Daher: E os repertórios não escritos por você, os de leituras, por exemplo?

Alberto Mussa: Eu comecei cedo a ler os clássicos. Em casa, tinha a coleção da Aguilar, do meu pai. Eu li todos aqueles romances: Dostoiévski, Tolstói, Machado de Assis, Eça de Queirós, tudo. E, os poetas: além de Camóes, gostava muito de Cruz e Souza, de Augusto dos Anjos... Castro Alves também era um poeta muito importante para mim, porque trazia o elemento negro, aquele que eu encontrava, digamos, nos terreiros, e que estava ausente de outras convivências sociais minhas. Então, por um viés afetivo, fui me interessando por assuntos como esse.

Teve um momento em que eu comecei a ler os livros do Círculo do Livro, que me trouxe a Literatura Brasileira Contemporânea. Eu já tinha lido Machado de Assis quase inteiro, mas não tinha lido Jorge Amado, Érico Veríssimo, Josué Montello. Nelson Rodrigues foi outra revelação, e é uma das minhas grandes referências. Gostaria muito de escrever como ele, mas não sei escrever como ele, escrevo completamente diferente! Mas acho genialíssimo, muito profundo, pouco estudado e pouco reconhecido. Nelson Rodrigues praticamente nunca foi traduzido, isso é uma coisa absurda. As peças estão traduzidas, mas os romances ficaram em segundo plano. $O$ asfalto selvagem, para mim, é um livro de referência.

Bem, quando comecei a descobrir essa literatura nova, passei a frequentar livrarias e sebos do centro da cidade. Então, vivia folheando e comprando os livros, conhecendo autores. Uma fase posterior começou quando passei a ler os clássicos estrangeiros, perto já de vinte anos. (Melville, Proust e tantos outros.)

Aconteceram comigo dois incidentes, em torno dos meus livros. Um deles eu contei em A desconstrução de uma biblioteca (texto que deverá ser publicado como apêndice, no ano que vem, num livro de contos). É a história de quando eu cheguei a ter quatorze mil livros 
em casa e, por causa do meu segundo casamento, tive que me desfazer desses livros. Eu me desfiz de mais de dez mil livros!

Outro incidente muito engraçado aconteceu na Faculdade de Matemática [em 1978, na UFRJ]. Meu pai era desembargador. Não era, naturalmente, um homem que compactuasse com tortura, com morte e nem com nada disso. Mas era um homem com um perfil conservador. Talvez por isso eu nunca tivesse ouvido falar de esquerda ou de comunismo na minha juventude, morando no Grajaú, e nem mesmo convivendo no meio da favela. Para nós, do Grajaú, os vermelhos e os maconheiros eram da Zona Sul. O pessoal do morro, inclusive, não se interessava por essas questóes ideológicas, como se não existissem esses problemas. Então, com 17 anos, quando eu entrei na Faculdade de Matemática, foi um impacto: eu comecei a saber que estavam acontecendo coisas no Brasil de que eu não tinha a menor noção. Noção nenhuma, nenhuma! Como sempre tive a mania de ter os meus livros — não gostava de apostila, não aceitava estudar em xerox, achava um absurdo — sempre comprava. Foi assim que comprei um livro de cálculo de um autor russo. Era uma tradução portuguesa, de Portugal. Gostei do livro e comprei para estudar cálculo.

Quando os meus colegas do Centro Acadêmico me viram com o livro de cálculo de um russo, eu fiquei muito popular. E recebi de presente um livro de poemas de Agostinho Neto, que era o presidente de Angola comunista. Foi assim que tive contato com a literatura africana, e isso foi um momento importante também. Descobri e comprei uma coleção inteira que a Ática estava publicando, naquele momento, de autores africanos. Os livros tinham uma capa muito bonita, muito colorida. Li vários desses romances, todos dessa coleção, e depois fui procurando outros. Alguns desses romances foram muito importantes, principalmente os de um escritor chamado Chinua Acheb, da Nigéria. Todos os textos dele são bons, mas dois livros são imprescindíveis: Flecha de Deus e $O$ mundo se despedaça, já traduzidos em português, pela Companhia das Letras.

Do outro lado, em casa, por conta do meu pai, adquiri também um conhecimento razoável da literatura clássica: conhecia as epopeias, a Ilíada, a Odisseia. Acho que a última loucura que fiz em termos de leitura foi, quando já maduro, com trinta e poucos anos, tentei ler Mitológicas, de Lévi-Strauss. Náo estou falando de influência diretamente, mas eu já li e reli essa série diversas vezes, e acho que ainda não consigo entender completamente tudo (não tenho formação em antropologia). De todo modo, o conjunto de Mitológicas é um trabalho tão espetacular, tão profundo... Ali você consegue encontrar uma coisa que é, ao mesmo tempo, profunda e próxima da gente. Também estão ali os nossos antepassados que contavam aquelas histórias. Mas, talvez, com essa leitura, eu tenha encontrado de novo aquilo de que sentia falta lá do início: o Brasil não tem civilização, não tem deuses, o Brasil não tem heróis, e todas as civilizaçóes do mundo têm.

Andrea Daher: Essa é a busca de origens de que eu falava. Mas há também uma busca 
por uma brasilidade, creio.

Alberto Mussa: Acho que sim. Pode ser que sim. Porque se eu não fosse brasileiro, eu teria me naturalizado brasileiro: gosto de ser brasileiro.

Mas gosto de literatura do mundo inteiro. A literatura, particularmente, é um espaço em que não se tem — pelo menos, não vejo assim — essa questão do nacional. O que existe é a matéria que você trabalha, a forma de trabalhar. Eu não percebo muito a literatura com divisóes nacionais, como literatura brasileira, literatura francesa etc., até porque o que lemos hoje é essencialmente um gênero internacional, um gênero ocidental.

Por exemplo, a literatura árabe tinha um perfil, características intrínsecas durante toda a sua história, mas a partir do século XIX, com a presença da colonização, os escritores árabes passaram a escrever gêneros que não eram nativos (vamos usar esta palavra entre aspas) daquela regiáo. Toda a literatura do mundo, da Índia, da China, hoje, pode carregar alguns influxos do passado, de tradição antiga, de outras estruturas literárias, de outras formas de conceber a literatura. É nesse sentido que a literatura que se pratica hoje no mundo é internacional, cuja origem é a Europa — ainda que a Europa, para formar esse padrão, tenha recebido influências também de outras origens. Mas, então, na verdade, considero o critério da língua muito fraco para definir nichos literários.

A língua portuguesa - caso se considere o português do Brasil a mesma língua que a de Portugal, e eu tenho dúvidas que seja — não seria o critério para definir uma literatura brasileira. Isso passaria a ser determinado pela nacionalidade: de quem, do autor? Ele, sim, pode ter múltiplas nacionalidades, pode ter múltiplas identidades! Então, não é esse o critério. Acho, inclusive, que uma compreensão da vida dos meus antepassados é uma coisa importante na minha estrutura afetiva e determinante do que eu escrevo. É por isso, talvez, que eu tenho uma relação forte com as religiôes africanas, já que o candomblé é totalmente baseado no culto dos antepassados. Isso, sim, é uma coisa importante!

Andrea Daher: Com esse seu procedimento de criar repertórios, como disse, muitas janelas são abertas ao longo do seu texto. É como um recurso de hipertexto, mas é sobretudo um procedimento digressivo, com efeitos, em certo sentido, metalinguísticos, metaliterários. Muitas dessas janelas estão relacionas com a introdução de um discurso mais próximo do mito. Penso que, justamente, a função do mito, no seu procedimento de escrita, é de desinstalar aquilo que há de mais clássico da literatura. Por exemplo, no caso do romance policial, você desinstala completamente o cientificismo (até mesmo porque o mito estaria no extremo oposto).

Alberto Mussa: Isso eu só fui chegando a perceber um pouco mais tarde. É porque quando você começa a escrever, não tem uma reflexão muito teórica sobre o seu próprio 
trabalho. É ao longo do tempo que você vai percebendo.

Andrea Daher: Mas, de todo modo, isso só é mesmo pensável a posteriori.

Alberto Mussa: É, isso só pode ser feito a posteriori, porque você não tem consciência na hora em que você faz.

Andrea Daher: Em todo caso, ao ler os seus romances, percebe-se que, com as janelas, você instaura uma espécie de paradoxo de temporalidades, alternando uma temporalidade histórica - por exemplo, um crime no Rio de Janeiro, no século XVI - e uma temporalidade mais profunda, originária ou mítica. Embora você forneça elementos que mostrem o quanto conhece do momento histórico (e o próprio personagem de $A$ primeira história do mundo, como você afirma, é verídico), esse paradoxo de temporalidades agrava o efeito de veracidade da sua narrativa.

Alberto Mussa: Chamado caso real.

Andrea Daher: Sim, é o chamado caso real, mas é um efeito. É real, sem ser real. É o real do livro de Alberto Mussa.

Alberto Mussa: Sim, é o apelo do caso real.

Andrea Daher: Enfim, com a entrada do mito na sua narrativa, em janelas digressivas, você burla a concatenação cronológica, a temporalidade da sucessão histórica.

Um outro recurso que atinge essa mesma finalidade é a invenção de uma persona, ao mesmo tempo historiador, detetive e mitógrafo. Ela assume várias entradas, que são falas na primeira pessoa, e, muitas vezes, o próprio escritor passa a se dirigir diretamente ao seu leitor.

A pergunta agora é a seguinte: de que modo esses recursos, considerando os deslocamentos que provocam (do cientificismo, da temporalidade, da narração), se relacionam com uma tradição de escrita literária? Para você, esses deslocamentos transformam, por exemplo, o romance policial, tal como praticado hoje? Você diria que, ao trazer procedimentos narrativos do mito ou da historiografia, produz algo novo num gênero há muito praticado, como o policial?

Alberto Mussa: Esses procedimentos, na verdade, eu descobri aos poucos. Acho que isso deve acontecer com a maioria dos escritores; é muito difícil que alguém comece com um livro genial. Até acontece, mas não é comum. Você aprende, é uma profissão. Não acho que nenhum livro meu seja genial, mas os primeiros não são tão importantes assim. São bem 
menos importantes porque eles têm defeitos. Os últimos estão mais aprimorados. Então, escrever é um trabalho, uma profissão. Você começa fazendo um livro e, à medida que você vai fazendo um segundo livro, vai adquirindo experiência, como em qualquer profissão, como qualquer profissional de qualquer área, seja um cirurgião, um professor ou um pedreiro. É à medida que ele vai evoluindo no seu trabalho que vai também controlando melhor a sua técnica, passando a se conhecer melhor, até o momento em que ele começa a enxergar bem o que vai fazer. Isso náo quer dizer que ele vai produzir as melhores obras nessa fase, quando tem essa visão.

Comecei a fazer isso numa situação totalmente casual. Eu já tinha escrito Elegbara e, depois, escrevi $O$ trono da rainha Jinga, quando entáo pensei em fazer uma série de cinco romances, um para cada século da história do Rio de Janeiro. Não seria necessariamente na ordem dos séculos (o que também é uma divisão arbitrária), mas seria apenas para ter uma meta estabelecida, porque quando você coloca uma meta, fica mais fácil de enxergar o projeto inteiro. Mas esse projeto das cinco histórias cariocas foi interrompido porque eu comecei a estudar árabe para fazer uma tradução de uns poemas pré-islâmicos.

Sempre gostei de línguas. Na universidade, eu me especializei em linguística. A minha dissertação de mestrado foi em linguística histórica: "O papel das línguas africanas na história do português no Brasil”. E, no doutorado, eu comecei a estudar as línguas tupi. Consegui desenvolver uma técnica, que a linguística me forneceu, que permite aprender qualquer língua muito rápido: não me preocupo em decorar o vocabulário, só preciso conhecer as regras; e as regras são finitas, um conjunto finito de regras. Em quinze dias você aprende qualquer língua. As línguas podem ser diferentes entre si, mas existe um princípio universal que você consegue aprender.

Então, comecei a estudar árabe porque tinha lido esses poemas pré-islâmicos e fiquei apaixonado por eles. Achava que aquilo tinha que ser aprendido na língua original. Meu interesse vinha, certamente, por uma questão afetiva, relacionada com as origens da família do meu pai, apesar de ter vivido completamente afastado dela por conta da distância (todos esses meus parentes são de Campos, só o meu pai veio para o Rio). Além disso, eu não tinha uma boa relação com o meu pai, que era muito difícil, muito severo, e eu sempre fui um pouco subversivo.

A tradução de Os poemas suspensos durou oito anos. Eu praticamente fazia um verso por dia; gastava três, quatro horas para traduzir um verso, porque eu sabia a sintaxe, conhecia as regras, mas não conhecia as palavras. Então, ia procurar palavra por palavra no dicionário. Depois juntava as palavras para tentar formar a frase que fazia sentido ali com aquelas palavras. Aí, tive que tratar das imagens, das metáforas, mergulhar em uma leitura sobre a Arábia pré-islâmica, saber quem eram aqueles beduínos. Li uma série de livros de história e até de etnografia contemporânea, muitos ensaios, e também comparei com várias traduçóes. Foi um trabalho demorado. E não foi possível sair para escrever uma ficção totalmente di- 
ferente, escrever outra coisa. Foi então que resolvi escrever $O$ enigma de Qaf, que é um livro que se passa na Arábia pré-islâmica também. É um livro com 28 capítulos, uma novelinha pequena. E logo entreguei o livro para o meu editor. Eu estava em uma fase ruim com a publicação de $O$ trono da rainha Jinga, que não tinha tido muitas vendas. Acho que isso é uma ironia da história: nessa época, quem escrevesse sobre assuntos brasileiros não aparecia, não conseguia romper a barreira da visibilidade literária; eu não tinha essa noção ainda, escrevia porque eu queria escrever.

Escrevi $O$ enigma de Qaf simplesmente porque estava envolvido com a tradução de $O s$ Poemas Suspensos. Mas meu editor rejeitou o livro por achar que estava muito fino. E disse: "Não dá certo, ninguém gosta de livro fino. É preciso aumentar." É o tipo de coisa que um editor pensa. Eu não tinha como aumentar, a história estava totalmente enxuta. Não tinha como mexer naquela história, estava pronta, se fosse mexer, estragaria. Eu conhecia os poetas pré-islâmicos de verdade, mas, nesse livro, o meu poeta era ficcional. Pensei, então: por que eu não comparo a vida desse poeta que inventei com a dos poetas que eu conheço, que eu já estava traduzindo? E fiz assim. Ficcionalmente também mudei um pouquinho, pequenos detalhes, não tudo, alguns mais e outros menos.

Esses poetas antigos teoricamente existiram, não sabemos. No meu livro, eu tinha 28 capítulos, portanto, 27 intervalos, mas só tinha 13 poetas. Tentei colocá-los mais ou menos equidistantes, a cada dois capítulos, mas achei que não estava esteticamente bom. Eu tinha mesmo que preencher os 27 buracos para o livro crescer. Foi aí que resolvi inventar uma mitologia árabe pré-islâmica — não usei fonte nenhuma, é tudo ficcional. Tentei criar um universo que fosse análogo, ou pelo menos compatível e que gerasse uma estética similar à da história que eu estava contando. E fui criando os mitos. Algumas histórias eu já tinha esboçadas para um livro que eu ia fazer de histórias fenícias. Como abortei esse livro, aproveitei as histórias para $O$ enigma de Qaf. Quando o livro ficou pronto, não foi publicado por aquela editora, e sim pela Record. Foi o livro que me projetou, o mais traduzido ao lado de O senhor do lado esquerdo (o meu último livro, A primeira história do mundo, não começou ainda a ser traduzido porque se espera sempre para ver se vai ganhar um prêmio para poder, então, fazer uma carreira melhor no exterior).

Felipe Charbel: Entre $O$ trono da rainha Jinga e $O$ enigma de Qaf tem quatro ou cinco anos de intervalo. Em termos de estilo e de construção, são narrativas muito diferentes. $\mathrm{O}$ primeiro com um estilo mais barroco, mais lento, com uma polifonia (cada capítulo tem um personagem diferente narrando). E o segundo tem mais o seu estilo, ou seja, o estilo das suas narrativas mais recentes: mais seco, mas ao mesmo tempo com muita fantasia, muito poético, muito cerebral, com uma arquitetura muito bem concebida. Como foi essa mudança? Você acha que, em termos de estilo e de arquitetura, foi em $O$ enigma de Qaf que você encontrou o seu jeito de escrever ficção? 
Alberto Mussa: É, ali começou. Mas, em $O$ enigma de Qaf, eu ainda uso o narrador que conta a própria história, em primeira pessoa. $\mathrm{O}$ passo foi dado no livro seguinte, $\mathrm{O}$ movimento pendular, que, acho, é o meu melhor livro. Se algum dos meus livros tiver alguma importância para a literatura, digamos assim, é este, que é um livro também de inventários. É uma história de adultério, que funciona, inclusive, como um sistema de previsão de todas as histórias de adultérios possíveis. Enfim, tudo começou no momento da publicaçáo de $O$ enigma de Qaf, meio por acaso: a história do editor que não quer o seu livro, você tem que aumentar o texto e encontrar uma solução para ele. Às vezes as coisas acontecem assim, por uma casualidade ou por uma dificuldade qualquer, e você inventa uma solução. Se eu não tivesse tido problema, talvez não tivesse escrito o livro; talvez tivesse publicado só a novela e ele deixaria de existir naquela forma. Mas foi justamente aquela forma que me deu algo especial: a possibilidade de escrever uma história, que pode ser a mais simples do mundo, uma história policial (que é, normalmente, mais popular).

Eu vejo hoje — talvez pela leitura de Mitológicas de Lévi-Strauss — que toda história pode ser compreendida, e que ela é mais compreendida quando comparada com outra. Você compreende melhor uma coisa quando você compara com outras situaçóes, duas ou mais. Quanto mais você comparar, mais percebe as diferenças. É como se a diferença entre as coisas, o contraste, fizesse sobressair a sua essência (não sei se essa é a palavra, mas, pelo menos, sei que a diferença amplia os significados, como se o contraste pudesse dar uma amplitude de compreensão).

Então, em O enigma de Qaf, por uma dificuldade editorial, descobri um jeito de escrever. A mesma história contada de outro jeito, do ponto de vista contrário. Esse procedimento, dominei melhor em $O$ movimento pendular, em que consegui o controle da técnica de sair fazendo outras histórias a partir de histórias que você leva como estímulo de base, de referência. É uma história que você pode recontar, e quando você reconta, também ressignifica, dá novas dimensôes, cria outras possibilidades estéticas, outros efeitos no leitor etc.

Depois disso, retomei o projeto dos romances cariocas, policiais, que era o que eu queria, porque me saturou demais esse período trabalhando com tantas realidades fora da minha. Escrever esses romances era uma oportunidade de viver um pouco mais a história da cidade do Rio de Janeiro. Isso pode parecer bobagem: eu já estou com 54 anos (espero viver bastante ainda), mas quando você está com mais de 50 anos, você tem que decidir o que quer fazer; você sabe que não vai fazer tudo, e eu sempre quis fazer tudo... Eu sempre quis, por exemplo, conhecer a literatura do mundo inteiro, conhecer todos os autores do mundo, e isso é impossível. Queria conhecer toda a história da América do Sul, e isso também é impossível. Queria, por exemplo, conhecer a mitologia de todas as etnias indígenas das Américas. E já tive coleçôes inteiras (maiores, agora já diminuíram) de livros sobre toda a etnografia, sobre todos os povos.

Queria também conhecer toda a história do Brasil. Mas, enfim, se eu conhecer a his- 
tória do Rio de Janeiro, já está muito bom, porque não dá tempo de conhecer tudo. Você depois percebe que não tem tempo para fazer tudo isso, e que tem que delimitar. Vivo no Rio de Janeiro e tenho relaçóes afetivas com esta cidade. Vivo intensamente a cidade: vou ao Carnaval; vou ao Maracanã um pouco menos (mas qualquer dia eu vou voltar); frequento os botequins e tenho amizades, nesses lugares. Então, quis voltar a escrever esses livros, que são menos cerebrais e menos esquemáticos do que os outros dois. A matéria deles exige que sejam feitos assim, porque são romances que se passam em ambientes que as pessoas conhecem. É diferente de $O$ movimento pendular, que é um livro que traz histórias que se passam na China, na Índia, na África. Então, ele é mais artificial, os outros são menos. Porém, eles têm o mesmo princípio: a comparação de casos. É assim no próximo livro também, que estou agora tentando simplificar mais ainda, tentando fazer uma, no máximo duas histórias. Espero que eu consiga discutir tudo o que quero, comparando apenas duas histórias. Eu tenho a história principal, mas não tenho a segunda história ainda.

Felipe Charbel: Gostaria de lhe fazer uma pergunta em relação aos seus dois últimos romances, que você gosta mais de chamar de novelas...

Alberto Mussa: É, eu gosto mais da palavra novela, acho mais bonita. Também são romances.

Primeiro, não gosto da palavra romance por causa da polissemia: quando se está em um meio não tão acostumado a esse vocabulário, que conhece menos os gêneros literários, se pensa que um romance é uma história de amor que tem um final feliz.

Se você comparar o romance clássico com a novela, o primeiro é muito mais psicológico, mais baseado em um só personagem, na vida de uma pessoa. Se fizermos um percurso profundo, analisando romances do século XIX, veremos que, normalmente, o título do romance é o nome de uma pessoa. E a novela é mais próxima do que seria uma narrativa policial, é mais fácil chamar de novela policial, do que de romance policial. Isso porque a novela, mesmo independentemente da extensão, parece ter uma agilidade maior. É como se o tempo interno dela fosse mais rápido, qualquer que seja o número de páginas ou o tempo que você leve para lê-la. Mas, se você pensar em um tempo ou um ritmo interior ao texto, trata-se de uma narrativa menor, que não é um conto nem um romance clássico. Ela é intermediária.

Às vezes uso as duas palavras, simplesmente porque eu náo gosto de repetir palavra. Uso, então, como sinônimos, para não ficar repetindo.

Felipe Charbel: As suas novelas são narrativas com um caráter histórico, mas elas não são romances históricos. Elas têm o equilíbrio entre a fabulação e o factual. Pendem para a fabulação que funciona como pretexto, um ponto de partida para criar uma atmosfera do século que você está querendo retratar. Para você, qual é a vantagem dessa fabulação mais livre? Qual é o ganho de pensar a história a partir dessa fabulação? Por que você optou por 
isso em vez do romance histórico clássico?

Alberto Mussa: O romance histórico clássico realmente recria o personagem existente. No caso dos meus livros, eu poderia dizer que eles são de ambientação histórica, e não romance histórico clássico; eles são ambientados no passado. Isso porque eu gosto de estudar, adoro estudar. Se existisse a profissão de estudante, eu seria estudante (isso é uma questão que talvez a psicanálise possa elucidar). Para fazer um livro, não costumo falar das minhas próprias experiências. Depois do livro que estou escrevendo agora, vou até tentar fazer isso: vou tentar fazer uns livros ambientados no Andaraí, onde eu vivi na minha juventude. Mas é claro que com trinta, quarenta anos de diferença, já passa a ser história e a personagem já é outra, outra pessoa.

Então, a história é um estímulo, porque me força a estudar, a ler os historiadores, a ler os textos da época etc. Assim vou aprendendo. E, por incrível que pareça, leio os livros de história tentando imaginar os cenários. Várias vezes, pequenos detalhes que são observados pelos autores chamam a minha atenção. Posso explorar isso literariamente. Eu acho que o meu processo de escrita necessita da leitura de textos de história para ser estimulante, já que eu defino previamente o período sobre o qual eu vou escrever.

O século XVI é para mim o mais interessante, porque é o menos conhecido e o mais misterioso: o século dos piratas, de grandes aventuras, do primeiro encontro do Ocidente com o mundo indígena. Eu acho muito estimulante esse momento para se pensar a humanidade. Quando pretendi escrever $A$ primeira história do mundo, já sabia que ia fazer um romance ambientado no século XVI, mas, eu não sabia qual era o assunto. Comecei a ler, a estudar.

Eu encontrei a história no verbete "Francisco da Costa", do Dicionário de Elísio de Oliveira Belchior, Conquistadores e povoadores do Rio de Janeiro. Pensei: É isso! Conservei os nomes verdadeiros de Francisco da Costa e Jerônima Rodrigues. É possível ir lá e ver, o verbete está lá. O que tem sobre o assunto está lá (é um verbete pequeno, não tem quase mais nada). E o resto do meu livro é ficção. Mas achei o caso com toda a cara do Rio de Janeiro. Me lembrei imediatamente do mito das amazonas, pensando na condição daquela mulher, ou nas mulheres em geral, através do caso dela, como um exemplo. Como deve ter sido difícil viver numa cidade, em uma sociedade, com tanta pressão! Uma cidade com mais homens do que mulheres, e uma mulher dessas resolve se casar com uma pessoa de classe baixa, tendo outros homens, não tão nobres, porém mais ricos, donos de terras, que estavam ali querendo se casar.

Essa personagem é uma rebelde, pensei, uma mulher que se insurgiu contra uma ordem de pensamento mais comum, então é uma personagem bem literária. Às vezes, você encontra um assunto assim, casualmente. Outras vezes não. $\mathrm{O}$ caso sobre o qual estou escrevendo agora é como uma história de família, uma história absurda, que eu ouvi há um tempo. E eu a transpus do século XX para o século XIX — isso não tem problema nenhum, uma história que aconteceu pode ser transposta para outro lugar, essa é mais uma das transformações que 
uma narrativa pode sofrer.

Andrea Daher: Você acaba de falar em "pensar a humanidade": essa intenção de dar uma "visão geral da condição humana" com a sua ficção, como você já disse uma vez numa entrevista, seria um fio da sua escrita?

Alberto Mussa: Se eu falei isso, foi muito ambicioso! O que eu quis dizer é que o único território que dá uma visão geral da condição humana é o mito. A literatura é sempre particularizante, e ela é muito ligada ao indivíduo.

Eu faço uma coisa provocativa. Tem uma tentativa de brincadeira nisso, mas é mais um espaço de delimitação, porque eu quero fazer um projeto de literatura que contemple certos assuntos, e esta é a minha maneira de estímulo para a escrita, que precisa de um planejamento prévio. Por exemplo, eu preciso traçar o plano do livro inteiro antes de começar a escrever. Mesmo que eu modifique alguma coisa, a base, a fundamentação dele, já existe. A começar pelo título: sem o título, o livro não começa, porque o título define a ideia, vai dizer tudo o que o livro é. Está no título um resumo da ideia do livro. Então, o título surge primeiro. $A$ primeira história do mundo: este título quer dizer alguma coisa muito importante. Não é um título casual, que o editor sugeriu.

Tive, no caso de $O$ movimento pendular, uma dificuldade, pelo fato de ter toda a tradiçáo literária para trabalhar neste livro; eu tinha que dar representatividade a todos os lugares do mundo, senão a tese implícita do romance não poderia ser validada - era uma teoria geral do adultério, então o livro teria que contemplar praticamente todas as culturas, todas as línguas, o que é impossível. É difícil lidar com um material tão amplo como esse. Seria mais fácil reduzir a biblioteca e ter apenas livros mais específicos para ler. Então, eu troquei uma biblioteca de história do Brasil por uma biblioteca de história do Rio de Janeiro, porque ela é menor e eu posso consultar os livros mais facilmente. É algo prático: esta biblioteca cabe dentro da minha casa. Então, tenho lá a história da iluminação no Rio de Janeiro, a história do gás no Rio de Janeiro, a história da saúde ou dos transportes no Rio de Janeiro... Porque se vou ambientar uma narrativa no século XVIII e o personagem vai de um lugar para o outro, ele precisa pegar um veículo, eu tenho que saber qual é esse veículo (até porque, numa história policial, esses detalhes são fundamentais: o tempo que você vai levar para percorrer uma distância, os tipos de provas que você tem, o conhecimento tecnológico etc.). Eu tenho também livros de armas, sobre todos os tipos de tiro. Eu sei tudo sobre como dar um tiro com revólver no século XVIII, porque a narrativa tem que ter verossimilhança. Então, você tem, às vezes, que fazer pesquisas funcionais, que são aquelas que vão preencher os aspectos de verossimilhança e materiais da narrativa.

O romance tem sempre muitas camadas; uma delas, meio superficial, é essa da concretude das coisas. Para descrever uma sala de uma casa do século XIX você tem que minima- 
mente conhecer um pouco do tipo de mobília, as madeiras etc. Por exemplo, uma pessoa rica, que tipo de móvel ela teria na sala? Teria um piano, teria um sofá de mogno. Então, você tem que conhecer tudo isso; esse estudo é muito gostoso, e isso é o que eu gosto de fazer. Outro dia, eu estava lendo sobre a história da arquitetura, não a do Rio de Janeiro, mas a do Brasil, de modo geral. É interessante a história da arquitetura, porque, ao ler, você vai lembrando das casas velhas em que já foi, das fazendas, dos museus, dos prédios históricos. $\mathrm{O}$ que está escrito nessas histórias você consegue reconhecer, depois, através da memória, e é importante para, você montar a descrição de uma casa onde, por exemplo, vai acontecer a cena de um crime. Como disse, é preciso que a narrativa seja verossímil para que as coisas aconteçam naturalmente naquele ambiente, naquela época.

Felipe Charbel: Pode-se dizer que a sua preocupação, quando vai escrever uma ficção ambientada em outro momento histórico, é reconstruir um clima, uma atmosfera. Isso é essencial para que uma correspondência entre as personagens seja verdadeira e consiga transportar o leitor. Nesse sentido, você acha que a narrativa produz algum conhecimento histórico?

Alberto Mussa: Sim. Por exemplo, você quer ver uma coisa: li dois livros sobre capoeira do Carlos Eugenio Líbano Soares, e achei esses livros fantásticos. É um trabalho historiográfico muito bem feito. Vi coisas ali fascinantes, profundamente literárias, estimulantes para você criar uma narrativa de ficção.

Para o próximo livro que quero escrever, quero aproveitar a história da capoeira (e, por isso, o livro está ambientado no século XIX). A literatura brasileira não tem quase nada sobre esse assunto. Pode-se ler alguma coisa em $O$ cortiço, de Aluísio Azevedo, uma cena dos carapicus e dos cabeças de gato, uma briga de capoeira, mas é uma coisa muito rápida.

Existe um livro, que está totalmente fora de catálogo, chamado Os capoeiras, de Plácido de Abreu [Moraes]. É um livrinho que não entrou na grande história da literatura, pois ninguém se lembra dele - é ficção, ficção ruim, mas é ficção. $\mathrm{O}$ autor, inclusive, nem era brasileiro, era português de nascimento, radicado no Rio de Janeiro, e era capoeirista. Ele fez até um glossário dos termos usados pelos capoeiras do século XIX, com o nome dos golpes, as gírias, a descrição da função das maltas, da distribuição geográfica. Então, justamente, nesse romance ele fala desses muitos aspectos ambientados num cenário fantástico — aspectos que, depois, a historiografia, com Carlos Eugenio Líbano Soares, por exemplo, ratifica e amplia.

Eu quero, nesse meu livro, colocar um pouco, pelo menos, dessa realidade, que para o brasileiro comum não existe, porque não é conhecida. E a capoeira não era uma coisa qualquer, era uma instituição fundamental da cidade, das ruas da cidade. Todos os escravos, todas as pessoas que conviviam no meio popular estavam mais ou menos envolvidas com a 
capoeira. E é, ao mesmo tempo, um tema extremamente aproveitável em termos de literatura, que mexe com uma série de situaçóes.

Assim, um dos constituintes do crime, no meu próximo livro, é o ambiente dos capoeiras, das maltas dos capoeiras. Enfim, não é exatamente querer passar um conhecimento histórico, como o historiador passa, porque o objetivo do romancista não é transmitir. Às vezes no romance histórico clássico se percebe isso. E é por isso que o romance histórico clássico pode se tornar ruim - nem todos, mas alguns. Porque a tentativa didática é superior, a tentativa é de explicar os contextos, por vezes economicamente, como se fosse um historiador tecendo um ensaio sobre o período. É assim que um romance se torna ruim porque é didático demais, e o autor quer mostrar que estudou, que sabe sobre o assunto; o livro perde a ficcionalidade, a rapidez e a agilidade ficcional, por conta desse tipo de postura. Não quero, de modo algum, transmitir um conhecimento que o livro de um historiador já transmite. Eu quero só reproduzir um ambiente.

Felipe Charbel: Mas, ao reproduzir um ambiente, de algum modo você transmite conhecimento. A perspectiva do leitor não cria o conhecimento? Esta não é uma reconstrução do passado feita com a intenção de construir uma verossimilhança histórica?

Alberto Mussa: Sim, mas não como conhecimento objetivo. O leitor não pode pegar aquele livro com essa intenção. Trata-se de verossimilhança, mas eu não sei se a verossimilhança - pelo menos nesse nível de intensidade — pode ser tida como conhecimento. Talvez ela seja apenas uma representação do passado que o leitor talvez não tenha tido e passe a ter. Mas a palavra conhecimento, eu acho muito forte! Este não deve ser o espaço do romance, não é esse o objetivo, mesmo que você queira que o seu texto seja verossímil; mesmo se, por exemplo, o crime tendo sido cometido com um revólver, você descreva um revólver que existia na época, para eliminar a licença poética ou literária de escrever coisas anacrônicas. Essa reconstrução do passado é um tipo de conhecimento que eu considero diferente, é um tipo de experimentação diferente.

Felipe Charbel: Algumas coisas que você costuma falar em entrevistas chamaram a minha atenção. Você disse, em uma entrevista recente ao jornal $O$ Globo, em uma matéria sobre tradução, que a sua literatura é chamada, até mesmo pelos seus detratores, de exótica. E você diz não ver problema nenhum nesse termo, porque o exotismo remete a uma tentativa de mostrar o outro, de mostrar uma diferença. Relaciono isso a uma frase que você sempre repete também em entrevistas: "Em literatura, só me interessa quem não sou eu." Você acha que a preocupação com o exótico — no sentido do outro, da diferença, daquilo que não é comum — realmente corresponde à sua literatura? Essa movimentação vai na contramão de tudo que é mais corrente na literatura contemporânea, que é muito autorreferencial, muito psicologizante. Nos seus romances, há sempre um narrador pesquisador que se preocupa 
com a forma do romance policial, e você até engana um pouco o leitor com isso...

Alberto Mussa: Tudo isso é proposital, para mexer com as pessoas, fazer uma provocação, uma brincadeira. Hoje eu percebo, muito claramente, que a minha matéria vai ser sempre a busca desse outro, que náo deixa de ser eu mesmo, porque eu sempre fui um pouco outro.

$\mathrm{Na}$ minha infância, nas minhas relaçóes no Grajaú, na escola, não tinha muitos amigos, porque os meus interesses eram diferentes: eu gostava do samba que tocava lá na quitanda, e não ia às festas que tocavam aquelas músicas americanas! A ideia do outro, de uma busca do outro mais radical, que vai além do folclórico, do superficial da cidade, do carioca, vai no sentido de perceber essas diferenças mais profundas.

O feminino também, por exemplo, para mim, é totalmente outro, é o meu oposto. Eu acho um desafio muito grande compreender as mulheres, do meu ponto de vista. São planos diferentes. É, por exemplo, como compreender, a partir do plano em que nós estamos hoje, o canibalismo dos Tupi antigos. Sempre tenho personagens misteriosas, porque acho uma pretensão muito grande fazer uma análise psicológica de uma mulher. Eu não sou mulher, eu nunca fui mulher, então não posso ter essa pretensão. Toda a minha visão é sempre a minha visão, é sempre totalmente parcial, totalmente masculina porque é minha. Posso apenas narrar fatos e tentar fazer com que provoquem o efeito.

É uma pretensão muito grande para o narrador fazer uma análise psicológica, porque é impenetrável o que se passa dentro de uma pessoa. $\mathrm{O}$ que você conhece dos outros são simplesmente os fatos que são expostos. Você não conhece o interior de ninguém. Então, a literatura psicológica, particularmente, é absurda. Não tem base, não tem fundamento.

Felipe Charbel: Eu queria lhe fazer uma pergunta sobre o livro que você escreveu com o Luiz Antônio Simas, Samba de enredo: história e arte. ${ }^{3}$ A definição de vocês me parece muito boa: o samba-enredo é um gênero épico, que nasce na cidade, no mundo contemporâneo, que vai na contramão dos gêneros populares, porque ele não é lírico.

A minha pergunta é a seguinte: se o samba-enredo não é um gênero estável, as transformaçóes recentes desse gênero não estariam deixando essa dimensão épica em segundo plano? Será que o samba-enredo não estaria se tornando um gênero muito descritivo, um amontoado, talvez desconexo, de citaçóes e de imagens para agradar os carnavalescos e os jurados de escolas de samba?

Alberto Mussa: Só para fazer um preâmbulo, eu diria que os gêneros épicos realmente desaparecem quando se começa a ter a presença do Estado, a chamada civilização, ou seja, o modelo estatal que substitui a vingança pela justiça, que reforça a noção de indivíduo,

\footnotetext{
${ }^{3}$ MUSSA, Alberto; SIMAS, Luiz Antônio. A. Samba de enredo: história e arte. Rio de Janeiro: Civilização Brasileira, 2010.
} 
de seus direitos. A literatura passa a ser lírica, e deixa a dimensão mitológica e épica para o passado, o fenômeno é esse.

Quanto ao samba, as pessoas envolvidas não têm conhecimento de poesia narrativa, então é bem surpreendente que tenha sido engendrado como foi.

Toda a história do samba é um processo de "desafricanização". Desde o século XIX, os instrumentos de percussão foram sendo substituídos e se introduziram as cordas. Tudo aquilo que é considerado mais bárbaro, mais selvagem é diminuído, abrandado, embora seja mantida uma certa sensualidade. Assim, enquanto nos outros gêneros de samba diminuem os tambores, a percussão, e aumentam as cordas - eventualmente aumenta o choro, explorando bastante o instrumento de sopro - , no samba-enredo os instrumentos de sopro começam a ser proibidos e as cordas só ficam para dar o tom do puxador, fazer uma harmonia mínima; o resto é só percussão.

Há diferenças também até na versificação, nas formas do verso, porque o verso português de sete sílabas é usado no samba. Já o samba-enredo não tem esse metro, ele é variado. Então, o samba-enredo tem um processo formal próprio, muito interessante, e as transformaçôes acontecem nas décadas de 1930, 1940, 1950, no momento em que os africanos já estavam distantes, não eram tão presentes.

Andrea Daher: As coisas de que você gosta, com as quais tem uma relação de afeto, você costuma sempre submeter a estudo? Além dos sambas-enredo, penso nas línguas, nos temas orientais também relacionados com a família do seu pai.

Alberto Mussa: Algumas coisas talvez eu tenha estudado, mas não sei se estudei tudo, não. Por exemplo, futebol eu nunca pensei em estudar. É uma coisa de que eu gosto muito, acompanho, mas não penso em estudar. Nunca pensei em fazer um livro sobre o Flamengo.

Mas sambas, já escrevi vários. Disputei dois sambas. Primeiro, um samba no Salgueiro, para o carnaval de 2009, que foi para a final. Foi um samba que ficou na internet, e foi o mais escutado, porque era um samba que tinha uma cara antiga, não tinha uma feição moderna. Então, causou sensação. Mas a escola não queria o samba, não queria desfilar com ele. E não ganhei por esse motivo, um motivo justo: todo mundo gosta, mas a escola não gosta. E disputei também pela Império da Tijuca, o enredo chamado Rainha Jinga. Este não foi para a final, foi cortado antes, na semifinal.

Mas há um samba, do Didi, $O$ amanhâ, que é baseado em um trechinho de uma música minha. Eu tenho mais de 200 músicas feitas: fiz muito ponto de macumba e ponto de capoeira, quando eu era jovem, tinha um grupo e fazia show. Eu não era um bom lutador de capoeira, mas eu tocava berimbau e cantava muito bem. Tinha cabelos compridos, cantava e tocava no berimbau os pontos de capoeira.

Como tudo na cultura africana é família, os descendentes da minha linhagem, do meu mestre de capoeira, ainda cantam essas músicas. E falam assim: "Essa música não é mais 
sua!" É aí que se vê como é o processo coletivo popular, que altera a letra, altera um pedaço da melodia, e a música original vai se perdendo, é bem legal.

Até pensei em ser sambista também, numa época. Mas não deu certo, eu não tinha talento para isso. Eu acho que o fato de o samba ser menos épico, realmente, faz com que, nas letras, apareça mais a alusão. Mas podemos considerar que essa é uma forma de narrativa. Ela não é tão estritamente, tão classicamente narrativa como o samba dos anos 1960, 1970, mas não deixa de ser uma forma de narração, com uma determinada sequência. Mas o que influencia a "epicidade" do samba é o enredo, porque quando você tem um enredo sobre iogurte, por exemplo, é quase impossível fazer uma coisa que emocione as pessoas, não tem como. A Beija Flor é realmente a grande escola nesse aspecto: a escola escolhe um enredo horroroso (o patrocinador fica satisfeito), mas consegue extrair uma sinopse que permite ao compositor fazer um samba que atinja esse tom épico.

O objetivo do desfile de carnaval do Rio não é divertir. Este é o objetivo do Carnaval de rua, que é universal. A diferença é que, com as escolas de samba, é um momento intelectual, é um momento para pensamento, não é para diversão, não é para se alienar. Ao contrário, o desfile das escolas de samba sempre se caracterizou por isso: é um momento de reflexão. Completamente diferente.

Nesse sentido, é uma lástima não termos um museu dos carros alegóricos. Imaginem se as escolas começarem a fazer enredos sobre a China dos Ming, ou a Índia, ou Mahabharata? Os carnavalescos ainda não conseguiram ver o potencial estético, visual desses temas. Acho que tudo está um pouco esquemático demais, sobretudo a criação visual das escolas de samba, que está um pouco cansativa, mas as escolas de samba não perceberam ainda.

Luiza Larangeira: A partir dessa sua crítica à criação estética das escolas de samba, volto à questão da literatura: gostaria de saber o que é criação literária para você? Como já foi dito, você é um inventariador e um refundador de origens: você gosta de inventar mitologias, pelo que entendi, por analogia a mitologias já existentes. No seu procedimento criador me parece que você segue no sentido de voltar às origens para produzir uma obra singular, única. Penso também no seu gosto, desde adolescência, pelo romance policial. Por exemplo, em Agatha Christie, tenho a sensação de que é um mundo completamente ordenado, e que o crime é algo fora da ordem. Mas, no final, reúnem-se todos os suspeitos, reordena-se o mundo, explica-se como as coisas funcionam, e cada coisa é posta no seu lugar. Do mesmo modo, para você, a volta às origens seria, ao mesmo tempo, colecionar e ordenar. Você diria, nesse sentido, que criar é ordenar?

Alberto Mussa: Você sabe que essa pergunta me deixou um pouco em dúvida, porque eu não sei, eu não pensei muito sobre isso. A criação para mim é quando eu consigo contar uma história. Primeiro, inventar uma história que gere um efeito, vamos dizer assim, num plano te- 
órico. Este efeito deve provocar alguma espécie de desconforto no estado que a gente considera como estabelecido e seguro, no dia a dia — por isso talvez a palavra ordenar não seja adequada.

Então, o que é a criação? É tentar contar uma história em que esse efeito possa ser produzido. Este é o desafio de criar. Em um processo de criação de um livro, você pensa em uma ideia geral; depois, você pensa em uma história, abstratamente; a seguir, você tem que escolher uma coisa muito difícil, que é o ponto de vista, o narrador, que é o chamado foco narrativo. Esse narrador, não é só a pessoa, a pessoa gramatical, é também tudo aquilo que ele vai conhecer, que ele vai narrar a partir do seu ponto de vista, que é um ponto no tempo e no espaço. De que conhecimento ele é onisciente, ou não é? Ele é onisciente em relação a alguns personagens, e não a outros, ou a todos? Então, tudo isso, por incrível que pareça, é a decisão mais difícil na hora de você fazer um livro, porque tudo do livro depende de como você narra, desse foco, se ele está bem construído e consistente para atingir o efeito, porque o leitor acredita nele. O pacto da leitura de ficção é esse: você compra o livro sabendo que é mentira, mas querendo acreditar que é verdade. É ficção, mas eu vou ler como se fosse verdadeiro. O que produz esse efeito é o foco narrativo, é isso que dá a segurança ao leitor.

O efeito pode ser produzido, por exemplo, por um narrador onisciente. $\mathrm{O}$ autor-narrador onisciente clássico é aquele que é capaz de falar da vida, desde o útero, de todos os personagens, conhece tudo. Às vezes o autor-narrador só é onisciente em relação a um pedaço: você narra em terceira pessoa, mas o seu foco está centrado em um personagem específico, vai depender da história. Um exemplo disso é o livro A primeira história do mundo, de que fiz três versóes. As duas primeiras eu joguei fora: quatrocentas páginas de livro jogadas fora por conta do narrador, que não produziu o efeito que eu queria. Foi depois que eu percebi que, para contar aquela história, o narrador não podia ser onisciente. É assim que você percebe que aquele efeito que você quer gerar náo vai acontecer porque o narrador está errado, a perspectiva tem que ser outra, é preciso mudar. Eu aproveitei uma parte ou outra. Mas, no geral, vários personagens foram embora (o livro tinha muitos personagens).

A criação literária envolve ainda a divisão estrutural da história, na sequência em que ela vai se desenrolar. A decisão a ser tomada é sobre qual cena deve ser narrada primeiro, porque os efeitos vêm daí (você esconde uma coisa aqui, faz aparecer ali etc.). E, no final, as palavras, as frases que você efetivamente escreve - mesmo para aquelas pessoas que dizem que escrevem no impulso, subjetivamente — têm que estar muito bem estruturadas, senão a narrativa não se desenvolve.

Acho que criar, fundamentalmente, seria isso. Ter uma ideia a explorar, provocar uma coisa qualquer. Se a gente pensar bem, a função - não gosto dessa palavra, mas não tem outra melhor - da literatura é provocar sempre um desconforto. Posso até dizer que a literatura, na verdade, se alimenta mesmo do mal. Ela precisa provocar alguma coisa, porque se ela for contar uma história boa, ou uma história que não tenha alguma coisa para gerar 
desconforto, ela não gera o efeito literário. Acho que toda história tem que ter esse efeito. Então, a função dela não é de apresentar verdades, não é de ordenar o mundo.

O que o romance policial tem de ordenação é a questão da solução do enigma, mas você também pode ter narrativas policiais em que não é preciso apresentar o resultado perfeitamente. Isso náo acontece no romance mais popular e convencional, em que você tem que ter a solução, senão o leitor náo gosta. Por exemplo, Crime e castigo, de Dostoiévski, é um romance policial, mas não é classificado assim, é considerado alta literatura. Mas é um romance policial em que o crime é totalmente revelado no início, e a tensão policial é a punição do criminoso, que se passa ao longo do romance até a expiação dele no final. É um romance policial invertido, que não tem quase mistério, mas é policial, com crime e investigação.

Andrea Daher: Pelo visto, você tem muitos projetos. E, de imediato, qual é o livro por vir?

Alberto Mussa: Quero abordar um problema que é o seguinte: o que é uma pessoa? Nesse sentido, as tradiçôes mitológicas divergem. Por exemplo, na tradição cristã ocidental, a alma é una, e por isso existe a reencarnação (como no kardecismo). Mas, na tradição do candomblé, por exemplo, a pessoa é constituída de três partes diferentes. Descobri ainda que entre os Guarani (que Nimuendaju estudou) existem pelo menos duas almas diferentes que coabitam. A noção de que o indivíduo é uno é como uma "posição neutra" que temos em nosso dia a dia: todo o mundo se pensa como uma pessoa una, pelo menos na nossa cultura. Então, quando essa ideia é deslocada, passamos a perceber e, até mesmo, a duvidar dessa "unicidade": este seria um efeito que eu pretenderia alcançar com este livro. Então, pensei em usar essa ideia das constituiçóes da pessoa em uma trama policial, na identificação de um crime. Para se identificar o assassino, se você tem três ou duas partes diferentes, como é possível? Que parte é o assassino? Pensei em pegar uma história policial e encaixar essa ideiazinha. Não tenho ainda como trazer essa discussão para a história que estou escrevendo agora, que tem um problema que vai ser resolvido por uma segunda história que tenho que imaginar ainda. Mas vou seguir nesse sentido.

Eu tenho escrito diariamente; tento, pelo menos, ler e escrever todos os dias. Este próximo livro deve ser pequeno em extensão, mas está demorando mais a sair justamente porque eu não tenho tido tempo muito para escrever. Eu queria publicar o livro em 2017, para terminar essa série e escrever outros. Tenho vários livros pensados, rascunhados, cinco livros que eu quero escrever antes de morrer. Se eu morrer, não vou conseguir escrever!

Mas isso não é uma obrigação, apenas queria escrever enquanto a vontade fosse essa. 